\title{
Den nordvestslesvigske Pietisme
}

\author{
Af F. Elle Jensen
}

Naar den nordvestslesvigske Pietisme hidtil er blevet behandlet, har det i Reglen været forbigaaende og som Baggrund for biografiske Skildringer af Salmedigteren H. A. Brorson, mens der ikke er fremkommet noget Forsøg paa at bestemme dens Udbredelse eller at give nogen samlet Oversigt over den, kun enkelte spredte Artikler og Meddelelser her og der, især i "Sønderjydske Aarbøger" og Carsten Petersens "Slesvigske Fræster". Ingen synes at have interesseret sig for det Materiale, der maatte findes i Bispearkiverne, men som den, der ensker at danne sig en Opfattelse af, hvad Pietismen har betydet for Vesterlandet, ikke kan undlade at efterse, fordi de, selv om de deri opbevarede Dokumenter ganske vist oftest handler om andre Ting, alligevel giver uundværlige Bidrag til Belysning af Forholdene.

I det følgende skal der forsøges givet en Skildring af Pietismen, som den udfoldede sig i nogle af Egnene mellem Ribe og Tønder, nærmere bestemt $\mathbf{i}$ de sønderjydske Dele af Ribe Stift, som laa Syd for 1864-Grænsen. En Behandling af Røret i og om Tønder vilde være betinget af Kendskab til de Generalsuperintendenten for Slesvig Stift tilstillede Præsteindberetninger, som desværre ikke blev afleveret efter Genforeningen, og om Ribe gælder det, at Byen skønt beliggende i Nordslesvig lige saa meget var en nørrejydsk som sønderjydsk Købstad. Hertil kommer, at Pietismen, som den udfoldede sig der, var 
udpræget kongerigsk betonet, for saa vidt som den havde sin Rod i københavnske, halvseparatistiske Kredse; desuden er den beskrevet andetsteds. Hvad de omliggende Sogne angaar, har de været saa nær knyttet til Stiftsstaden, at det er berettiget at behandle deres Kirkehistorie sammen med den, hvilket for Pietismens Vedkommende ogsaa sket. ${ }^{1}$ ) -

Naar den nordvestlige Del af Sønderjylland ved Svend Estridsens store Stiftsreform c. 1060 ikke, som man kunde have ventet, blev lagt under Slesvig, men derimod under Ribe Bispestol, bunder dette utvivlsomt i ældgamle topografiske Forhold. Oprindelig spærrede nemlig de mægtige Farrisskove for den direkte nord- og sydgaaende Trafik, som derved blev tvunget til at søge vestenom, hvor Terrainet var lettere passabelt, saa der allerede tidligt kom til at gaa Veje fra forskellige Steder paa $\varnothing$ stkysten over mod Hjerting-Ribekanten. Den Forbindelse, som saaledes naturligt knyttedes, blev imidlertid delvis brudt ved Anlæggelsen af den store Hærvej Slesvig-Viborg, der ikke kun aabnede Skoven, men ogsaa gjorde Slesvig til Hovedby i hele Østlandet. Midtlandet holdt derimod fast ved de tidligere Færdselsaarer og følte sig stadig saa nær forbundet med Vestkysten, at disse Egne, det vil stort sige alt det, som laa Vest for Hærvejen og Nord for Vidaaen, ganske selvfølgeligt gled ind under Ribebispens Tilsyn.

Denne Ordning bestod uanfægtet hele Middelalderen igennem, men efter Reformationen lykkedes det efterhaanden de holsten-gottorpske Hertuger, der onskede at frigøre deres Besiddelser for al kongerigsk Indflydelse, at faa saavel Tonder Provsti som Løgumkloster Amt, Hellevad, Egvad og Bedsted Sogne losrevet fra deres gamle Forbindelse og underlagt Slesvig Stift, hvor de siden forblev. Hvad der blev tilbage, bestod af det allermeste af Tørning Len, Møgeltønder og Ballum Birker, Lø Herred, Emmerlev i Højer Herred samt Amrum og For Vesterland. ${ }^{2}$ ) 
Vesterlandets Tilknytning til Ribe havde b!andt andet til Følge, at den Orientering mod Tyskland, som allerede i Midde'.alderen mer eller mindre gjorde sig gældende indenfor den slesvigske Gejstlighed, og som i stigende Grad fortsattes efter Roformationen, ${ }^{3}$ ) ikke sporedes videre hos Præsteskabet her, idet det i alt Fald fra 1629 som hørende til et dansk Stift var forp'igtet til at have studeret ved og taget Eksamen fra Københavns Universitet. At enkelte Præster ogsaa opholdt sig en Tid ved tyske Højskoler, var Undtagelser, som intet ændrede i den Kendsgerning, at den nordvestslesvigske Gejstlighed helt igennem var danskpræget. I Tiden $1700-1848$ studerede $81 \mathrm{pCt}$. af den alene i Danmark, 15 pCt. i Danmark og Tyskland og kun 2 pCt. blot i Tyskland. ')

Befolkningen følte sig da ogsaa i kirkelig Henseende fast knyttet til sin Stiftsstad, og hvad de gudstjenstlige Former og det, der dermed stod i Forbindelse, angaar, var Forholdene stort set som i det egentlige Danmark, om end nok enkelte fremmede Skikke i Tidens Løb kunde smutte ind. 1629 fastsloges det vel udtrykkeligt, at ,in rebus ecelesiasticis ${ }^{\text {(“i) }}$ ) skulde man i de sønderjydske Dele af Ribe Stift følge de samme Regler som i Kongeriget, men denne Bestemmelse blev ikke ganske uanfægtet. Dette skyldtes de indviklede Tilstande, der fulgte af, at Egnen i verdslig Henseende bortset fra Enklaverne hørte til slesvigske Amter, og at man i den Anledning Gang paa Gang mente sig berettiget til derfra at gribe ind ogsaa $i$ de kirkelige Anliggender, som ellers kun vedkom Biskoppen i Ribe, noget, der stadig førte til mange Konflikter mellem Parterne. Naar hertil kom, at det danske og det tyske Kancelli i København med Hensyn til Afgorelserne ofte trak hver til sin Side, forstaar man, at det tidt kunde være vanskeligt at danne sig et Skøn om Tingene, og at disse let om end paa mindre væsentlige Punkter kunde komme til at te sig noget forskelligt Nord og Syd for Kongeaaen. ${ }^{6}$ )

1724 fik Præsterne saaledes Ordre til at ho!de Paaske efter tysk Skik, 8 Dage før i Danmark, og 1735 indskærpedes det 
Gejstligheden i Tørning Len ved Trolovelse og Bryllup at rette sig efter de i Haderslev Amt gældende Regler (Vielse i Bosættelsessognet, altsaa i Praksis Brudgommens Sogn), men 1757 at følge dansk Skik (Brudens Sogn) og 1763 at gaa en Mellemvej (Brudgommens Sogn, om Bruden i Forvejen havde bosat sig der). Kom hertil, at Kirkernes økonomiske Forfatninger, Embedernes Indtægter og visse Kirkeskikke var forskellige, var det ikke sært, at Præsterne tidt hverken vidste ud eller ind. At Dele af Sognene, undertiden ganske smaa, en Gaard, et Hus eller en Mark, som nørrejydske Enklaver verdsligt hørte under dansk Jurisdiktion paa samme Maade som de store kongerigske Enklaver, Lø og Møgeltønder Herreder, i hvilke der paa den anden Side var adskilligt slesvigsk Storgods, bidrog kun til at gøre Forvirringen yderligere og gav hyppigt Anledning til Strid mellem Befolkning og Embedsmænd. ${ }^{7}$ )

I religiøs og moralsk Henseende har de nordvestslesvigske BønJer staaet paa samme Stade som Befolkningen i det øvrige Danmark, og naar Carsten Petersen mener, at de logumkloster. ske Klerkes Arbejde i Middelalderen har sat særlige aandelige Spor mellem dem, turde det bero paa en Forveksling med den større Alvor, som vistnok kendetegner Vestjyderne i Almindelighed. Man kan gaa ud fra, at Almuen overalt i Danmark i Kraft af sin ensartede Undervisning har haft samme ortodokse og konservative Indstilling til Kirke og Kristendom, og da de sønderjydske Sogne under Ribe benyttede baade den danske Salmebog, det danske Ritual og den danske Gudstjenesteordning $i$ det hele, er det kun rimeligt at slutte, at Menighedstilstandene ikke har været stort anderledes, end de f. Eks. var i Norrejylland.

Dette bekræftes af de Andagsbøger, der fandtes i Hjemmene. Det er Skrifter som Henrik Müllers Postil, Joh. Arnds "Sande Kristendom“ og „Paradisets Urtegaard“, Lassenius' „Bibelske Kærne“ og Hvalsøes „De bedendes aandelige Kæde“, man møder i Skifteprotokollerne, og da deres Indhold stort set 
er præget af den lutherske Bodsfromheds Tanker, faar man derigennem et Fingerpeg om, hvilken Aand Bønderne ønskede, skulde raade i deres $H$ jem. Afdøde Dr. Laust Moltesen, der var født i Hviding Sogn, har i et privat Brev til mig oplyst, at Frederik II's Bibel gik i Arv i hans Slægtsgaard, og at der indtil sidst i 1700-Tallet indførtes Bemærkninger i den. Hver Morgen samlede Husfaderen Folkene og læste et Stykke af den for dem og hveranden Sondag og Juleaften noget af Brockmands Huspostil, og det var en fast Skik, at Mand og Kone skiftedes med Tyendet til at søge Kirken hveranden Helligdag. Scrivers „Sjæleskat" i to Kvartbind med Spænder og forgyldt Snit og Arnds „Sande Kristendom“ hørte ligeledes til i Familien.

Men Befolkningens oprigtige Kirkelighed gik som i Jylland Haand i Haand med megen Overtro. Provst Vedel i Daler (1705-30) beretter saaledes, at Bymænd i et af Herredets Sogne, oven i Kobet med Præstens Tilladelse, som et Værn mod Kvægsyge fremgned ny Ild, efter at al anden var slukket i Husene, og derpaa drev deres Kreaturer gennem Røgen, ligesom der blev smøget i alle Stalde, og Folk tog Brande af den ny Ild med hjem. ${ }^{8}$ ) En Mand i Bevtoft, der fandt sin halshuggede Hane udenfor sin Gaard, fik sine Bysbørn til knælende at bede Fadervor og under Haandspaalæggelse anraabe om, at Gerningsmanden maatte blive fundet.") Og saa sent som i 1760 erne trængte en Dreng, der ikke kunde ligge tørt, sig under Gudstjenesten ind i Tirslund Kirke og blandt de knælende Nadvergæster frem til Alteret, slog i det og bekendte sin Sygdom.")

Heller ikke de moralske Tilstande var anderledes end andre Steder i Kongeriget og Sønderjylland. Det vil sige, at her som der har Befolkningen været temmelig hengiven til Drikkeri, og at det med Hensyn til Sædeligheden ogsaa har ladet adskilligt tilbage at ønske. Julestuer, Fastelavnsløben, Kortspil o. a. har overalt været almindelige, uden at man i nogen Maade selv har taget Anstød deraf eller følt sig i Modsætning til Kirken, der paa Grund af Folgerne altid havde set paa dem med 
umilde Øjne. En vis Undskyldning kunde man sine Steder have $i$, at Gejstligheden heller ikke altid holdt Idealets Fane højt, thi om end de allerfleste Præster utvivlsomt levede et roligt og ærbart Liv og passede deres Forretninger til deres foresattes Tilfredshed, var der alligevel en Del, som ikke var alt for nøje1єgnende med, hvad de foretog sig. „Det gaar an,“ sagde Spandet Præst, de bar ham til Kroen," skal referere sig til $\mathrm{Hr}$. Jens Peter Møller, der 1660 fik Kaldet og havde lovet ikke at gaa til Kros, men den folkelige Vittighed om ham kunde rimeligvis i modificeret Form anvendes om mange af hans Kolleger. ") Det kunde ogsaa gaa galt i Forholdet til det 6. Bud, saa Præster blev udlagt som Barnefædre, og Hr. Chrystalsin i Branderup maatte 1730 bekende for sine foresatte, at hans Hustru - Formandens Enke og i Forvejen Moder til 10 Børn - var nedkommet med Tvillinger 14 Uger for tidligt. Sagtens for at forbedre sin Situation oplyser han samtidig, at de var fuldt saa store som andre Børn! ${ }^{12}$ )

Naar Sønderjylland fik Forbindelse med Pietismen før det egentlige Danmark, skyldtes det ikke kun dets Beliggenhed, men lige saa meget den Omstændighed, at Gejstligheden i Slesvig Stift som før nævnt følte sig nærmest knyttet til tysk Aandsliv. Af Præsterne i Aabenraa Amt studerede saaledes i de 17. Aarhundrede 15 i Rostock, 10 i Kiel, 6 i København, 3 i Kønigsberg, 3 i Wittenberg, 2 i Leipzig, 1 i Jena og 1 i Dorpat, ${ }^{13}$ ) saa det var ikke sært, at de paa Forhaand var mere modtagelige for kirkelige Strømninger sydfra, end man var i Kongeriget. Ganske vist var Flertallet ortodokst, men navnlig i Byerne var der dog nogle, der blev grebet af den nye Bevægelse. En Forløber for den var Fr. Brekling, ${ }^{14}$ ) der 1660 maatte Lidvandre til Holland, fordi han i et Flyveskrift, havde hævdet, at Præsterne ikke levede i Overensstemmelse med Evangeliets Krav, men som ved sine Skrifter, der gennemtrængtes af et pessimistisk og sværmerisk Livssyn, vedblev at øve en vis Indflydelse i sin Hjemegn, især i Flensborg, hvor kirkelige Bryd- 
ninger i Aarene omkring 1700 (Strandiger) tildels kunde føres tilbage til hans radikale Anskuelser. I Fjolde virkede Breklings Fætter, Diakon Petri ( $\dagger$ 1695) og blev dér Anledning til en stor Vækkelse, men ellers synes Pietismen paa dette Tidspunkt ikke at have gjort sig videre gældende, om end nogle Præster stod den nær; det var saaledes Tilfældet i Flensborg, hvor de fleste indenfor Gejstligheden en Overgang var venligt indstillet overfor den.

Naar da Konfirmationen i denne Periode blev indført adskillige Steder i Slesvig Stift, skyldtes det heller ikke Pietismen og dens Krav om en aandelig Paavirkning af de unoe alene, men lige saa meget det ortodokse Ønske om at indprente dem den rette Lære; betegnende i saa Henseende er det, at den Mand, der mere end nogen anden var ivrig for den nye Kirkeskik, Provst Arnkiel, ikke var egentlig Pietist, om end under Indflydelse af Spener og Groszgebauer ${ }^{16}$ ) og deres Syn paa Daabspagtens Fornyelse, og at han kunde arbejde for Sagen i god Overensstemmelse med sin ortodokse Generalsuperintendent (Sebastian Niemann). 1691 cg 1693 blev Konfirmationen lovformeligt paabudt $i$ den kongelige og den gottorpske Del af Stiftet og trængte derefter lidt efter lidt igennem i Pastoraterne; nogle Steder varede det dog længe, inden det skete, i Valsbøl saaledes ikke før 1740, i Udbjerg 1739, i Hostrup 1734.

At Pietismen $i$ forste Omgang bortset fra Flensborg og Fjolde ikke gjorde sig synderlig gældende i Slesvig Stift, hænger maaske ogsaa i nogen Maade sammen med den ringe Støtte, den fik fra det theologiske Fakultet ved Universitetet i Kiel. Blandt Professorerne stod Chr. Kortholt ( $\dagger$ 1694) i Forbindelse med Spener, og han øvede nogen Indflydelse paa Provst Arnkiel, men han indtog ikke noget særligt afgjort Stade og fjernede sig efterhaanden delvis fra Pietismen. A. H. Francke havde som Student i Kiel boet hos ham. Mere udpræget og betydeligere var Henr. Muhlius ( $\dagger 1733$ ); han var en kraftig og stridbar Personlighed, der nok forstod at hævde sig og vel ogsaa har 
gjort Indtryk paa nogle af Studenterne, men der høres alligevel ikke om egentlige Resultater af hans Virksomhed. Til Pietismen henregnedes ligeledes Alb. zum Felde ( $\dagger$ 1720) og Joh. Fr. Mayer ( $\dagger$ 1712); den sidste slog ganske vist senere om og blev en af Retningens Modstandere.

I det hele taget havde den Pietisme, der hidtil var kommet til Orde i Slesvig Stift, ikke vist sig i Besiddelse af nogen større Slagkraft - kun lokalt havde den enkelte Steder gjort sig gældende - eller fostret nogen særlig fremragende Personlighed, der var i Stand til i videre Udstrækning at gøre Indtryk paa de brede Lag, og den havde heller ikke kunnet springe over Gærdet til de sønderjydske Dele af Ribe Stift. Naar der nu skete et Tilløb hertil, skyldtes det baade, at Enevold Evald fra Højst var en betydelig Mand, og at Sagen for ham stod saa meget over Formerne, at han uden Hensyn til de ellers uoverstigelige Stifts- og Sogneskel i Praksis turde vedkende sig det almindelige Præstedømme, hvad den pietistiske Gejstlighed alle Teorier til Trods plejede at have meget svært ved, og tage et missionerende Arbejde op, naar og hvor han følte sig kaldet til det.

Allerede hans Fader Nicolai Evald, Sognepræst i Højst 1693 -1733 , maa vist have staaet venligt til Pietismen. Der vides om ham, at han holdt Bønnemøder med sine Sognefolk, og at han lod sin Søn studere ved Hovedkvartererne i Jena og Halle, peger i samme Retning. 1718 vendte denne hjem for at hjælpe sin Fader med hans Embedsforretninger, stærkt grebet af den Aand, han havde mødt ved de tyske Universiteter, og opfyldt af brændende Iver efter personligt at vidne om det, der optog hans Sind. Det varede derfor heller ikke længe, inden han begyndte at udlægge et eller andet Skriftsted eller noget fra Katekismen, først i Familiens Kreds og siden, da flere og flere ffterhaanden kom til, med sin Faders Tilladelse i Kirken. Der indledtes med en Sang, derpaa talte han et Kvarters Tid, staacnde i Skriftestolen, og der sluttedes saa med Bøn og Sang. 
Saadanne Sammenkomster var ganske ukendte paa Egnen, og de vakte stor Opsigt, ogsaa fordi Evald var i Besiddelse af en ikke helt almindelig Veltalenhed og med sine indtrængende Ord vidste at gøre stærkt Indtryk paa sine Tilhørere, og en af Præsterne i Nabolaget - der vides ikke hvem - fandt sig desaarsag befejet til at indberette Sagen for Provst Reimarus i Tønder. Provsten var ganske vist selv Pietist, men alligevel forekom det, der foregik i Højst, at en uordineret prædikede, ham saa usædvanligt, at han afkrævede Sognepræsten en Erklæring.

Nic. Evald tog imidlertid afgjort sin Søns Parti og svarede, ${ }^{16}$ ) at han selv havde overværet de omtalte Forsamlinger og med Glæde set, at der var Sjæle, som gerne vilde hore Guds Ord, saa han kun kunde ønske dem al Fremgang. Og for Resten vilde han gerne vide, med hvilke Ord, ud fra hvilket Sindelag og i hvad Hensigt ${ }^{17}$ ) den paagældende Præst havde gjort Anmeldelse. Hans Son var villig til at lade sig eksaminere angaaende sin Lære. Provsten forbød ikke desto mindre Evald at tale ved disse Sammenkomster, og han adlød. Alligevel gik Rygtet, at han fortsatte, og en ny Klage indgik over ham, saa hans Fader atter maatte tage ham i Forsvar og skrive til Reimarus, at han med højeste Forundring ikke kunde begribe de Usandheder, der blev forebragt om disse collegia pietatis, endnu før man havde faaet nøjagtig Underretning om dem. Han vidste nok, hvorledes man i sit Embede skulde respektere overordnede ${ }^{18}$ ) og han kunde forsikre, at hans Søn siden Forbudet hverken havde talt i Skolen eller i Kirken.

Enevold Evald maa dog igen siden være begyndt med at holde gudelige Forsamlinger, thi snart opstod der ved ham ogsaa Røre i de omliggende Byer, Løgumkloster, Burkal, Ravsted og Bedsted, hvor allerede den unge Præst Nicolai Brorson havde sluttet sig til Pietismen og derfor let kunde samarbejde med ham. ${ }^{19}$ ) Foruden gennem det mundtlige Ord virkede han $r$ d smaa Piecer, som han fik trykt i Flensborg og Tønder, men 
iøvrigt ved man ikke stort om, hvorledes Vækkelsen opstod de forskellige Steder. I Løgumkloster skal allerede 1707 Landsbylærer Andr. Rachebrand, siden knyttet til Vajsenhuset i Tønder, være optraadt som krads Pietist og have vekslet Stridsskrifter med Provsten i Aabenraa om Lovens Gerninger og gode Gerninger, men om hans Betydning for Egnen foreligger ellers intet. $\left.{ }^{21}\right) 1721$ besøgte Evald Byen og vandt stærk Indgang med sin paa een Gang baade følelsesbetonede og alvorlige Omvendelsesprædiken, og der fortælles, at Bønderne derefter i den Grad lagde deres Liv om, at de selv paa Marken samledes til Andagt. ${ }^{21}$ ) I Løgumkloster var just dengang $\mathrm{H}$. A. Brorson Huslærer hos sin Morbroder, Amtsforvalter Nic. Clausen; han var netop paa det Tidspunkt inde i en aandelig Gæring, og der kan næppe være Tvivl om, at Evald har haft stærk Indflydelse ogsaa paa ham og dermed paa hans fremtidige Udvikling.

De kirkelige Myndigheder i Slesvig Stift vedblev imidlertid stadig at være yderst utilfredse med Evalds Virksomhed, ogsaa Superintendent Clausen, saa naar der ikke blev skredet alvorligt ind mod ham, skyldtes det, at den indflydelsesrige Statsminister J. G. Holstein, der samtidig var Amtmand over Tønder Amt og selv Pietist, sørgede for, at der ikke skete ham noget. Hvor afvisende Øvrigheden kunne staa overfor den af ham fremkaldte Bevægelse, fremgaar med tilstrækkelig Tydelighed af den Klage, Præsten i Logumkloster, Roost, 1727 tilstillede den derværende Amtmand over de ,irregulære Forsamlinger“, hvor Lægmand udlagde Skriften, da Evangeliets rene Lære muligt dermed led Skade, og Vranglære opstod. Amtmanden var fuldstændig enig: De paagældende Sammenkomster var baade utilladelige og strafbare, saa meget mere som Menigheden jo i Guds Hus paa regulær Vis blev undervist i den sande saliggørende Tro, og han forbød derfor at forsamles paa den ovenomtalte Maade uden Tilladelse. Overtrædelse af Forbudet vilde medføre en Mulkt paa 10 Rdl., eventuelt Legemsstraf. ${ }^{22}$ )

Det Rørc, der kom til at staa om Evalds Navn, skadede ham 
imidlertid ikke paa højeste Sted, hvor sikkert Grev Holstein har talt hans Sag. Følgen var, at han 1727 blev kaldet til Lærer og kort efter til Præst ved Vajsenhuset i København. Ogsaa her kom han stærkt i Forgrunden, og han blev en af den just da i Hovedstaden kraftigt fremtrængende Pietismes første Mænd. Men en Skildring heraf hører ikke hjemme i denne Fremstilling.

I det foregaaende har der været talt om Evalds Virksomhed i Slesvig Stift. Men at han heller ikke har været ræd for at overskride dettes Grænse, ses af, at han ogsaa har holdt Forsamlinger i Møgeltønder. Den stedlige Præst, Henningsen (1709-30), angreb ham i den Anledning voldsomt fra Prædikestolen og veg end ikke tilbage for at beskylde ham for et utilladeligt Forhold til en ung Pige, men han maatte snart tiltræde et Tilbagetog, ja tilsidst give ham Tilladelse til at tale $i$ Kirken. ${ }^{z 3}$ ) Han har ligeledes haft Forbindelse med den pietistiske Præstefamilie Vedel i Døstrup, mest naturligvis med Sønnerne Søren og Peder, der var hans jævnaldrende. De havde som han læst ved tyske Universiteter, og paa deres Hjemegn havde de nu, besjælet af samme Aand, taget et nidkært Arbejde op. De gjorde Husbesøg, uddelte Ny Testamenter og holdt Møder med Bønderne under Bøn, Salmesang og Oplæsning i Arnds „Sande Kristendom". Hvorvidt ogsaa Evald har ført Ordet ved saadanne Lejligheder, vides ikke, men det kan i alt Fald ikke anses for usandsynligt. Søren blev 1722 Kapellan hos sin Fader og Peder samme Aar Præst i Stauning ved Ringkøbing, hvor hans Fcrkyndelse gav Anledning til en stor Vækkelse. ${ }^{24}$ )

I Døstrup ${ }^{25}$ ) havde allerede længe forinden de unge Mænds Fremtræden deres Fader Nissenius Vedel (1685-1737), en Sønnesøn af Anders Sørensen Vedel, virket kraftigt i Tilslutning til Pietismen. Det har næppe været den tunge Tilskikkelse 1696 at miste 6 Børn ved smitsom Sygdom, der bragte ham i Forbindelse med den, det er vistnok allerede sket tidligere, for- 
mentlig gennem Læsning af Speners Skrifter, thi allerede 1693 fik han bygget en Skole, "den forste her i Landet", ग: paa Egnen. Han katekiserede flittigt, uddelte Ny Testamenter, holdt Bedetimer ved Aftensang om Sommeren og talte saa længe og stærkt mod den gængse Juleleg og Fastelavnsløben, at begge Dele tilsidst forsvandt. Bønderne fik han til at købe Salmebog og at synge med ved Gudstjenesterne, hvad de aabenbart ikke havde været vante til; selv plejede han at gaa op og ned ad Kirkegulvet for at stimulere Sangen.

Kirkegangen tog i hans Tid meget til. Hidtil havde der været god Plads ved Gudstjenesterne, men allerede 1692 maatte han soge om og fik bevilget $300 \mathrm{Rdl}$. til Opsætning af Pulpiturer; i hvor høj Grad Menigheden var med i dette, fremgaar af, at nogle Bønder, som fik Stolestader her, tilbød aarligt at yde en Afgift derfor, der da skulde gaa til Afbetaling af Summen. 1718 anskaffedes 4 Skamler til Skolebørnene, men 1734 maatte selve Kirken udvides, da den ikke kunde rumme alle dem, der søgte den, maaske blandt dem ogsaa nogle fra andre Pastorater. Man forstaar, at der har kunnet samles endogsaa overmaade mange om Vedels Prædikestol, naar man hører, at det nu mentes nødvendigt for et Scgn paa c. 700 Indbyggere at have 344 Siddepladser. Altergæsternes Antal var ligeledes stort; 1737 angaves det til 1133.

Det var Vedel, som stod bag Udvidelsen, der imidlertid gav Anledning til nogle Rivninger med Trøjborg, som „ejede“ Kirken, og med Schackenborg, hvortil nogle af Bønderne hørte, og det kom til Proces, fordi man mente, at han var gaaet for egenmægtigt til Værks. Ligeledes søgte man at lægge Pres paa Kirkegængerne ved at formene dem at benytte de dem nyanviste Stole, og da nogle af dem heller ikke var tilfredse med dem, fordi de fra dem ikke kunne se Alter og Prædikestol, opstod der en vis Urc. Biskop Anchersen i Ribe, der skønnede paa Vedels uselviske Arbejde, greb da ind i Striden med en Henvendelse til Schackenborg om ikke at gøre „de skraalske Bønder endnu 
galnere i Hovedet", men faa dem til at falde til Ro, og personligt tilføjede han til sin Ven, Godsforvalter Lehmann, der havde været temmelig kamplysten: „Djævelen skal tage dig, hvis du ikke hurtigt indstiller Processen mod den den lille Helgeni Døstrup $\left.^{26}\right)$ - en vist for Brevskriveren ret karakteristisk Vending. Processen, hvis Gangikke kendes, førte dog ikke til noget afgorende Brud mellem Vedel og Herskaberne, særlig det paa Trøjborg, hvor baade Ejeren, Buchwald, og Godsforvalter Clausen - tidligere i Løgumklcster - stod Pietismen nær, og han kom ikke til at gøre nogen Afbigt for sine eventuelle Overgreb i Byggesagen.

1709 havde man i Døstrup forsøgt gennem en frivillig Ordning af Fattigvæsenet at komme Tiggeriet til Livs, men baade da og 1723 mislykkedes det. Vedel opgav dog ikke Sagen, og 1726 fik han efter forudgaaende Drøftelse paa et Landemode nye Vedtægter udarbejdet, ligesom han fik Bønderne til at yde baade Materialer og Arbejdskraft til det Fattighus, der 1727 byggedes ved Skolen. Her blev der Plads til 4 ugifte Kvinder, der var født eller havde boet i Sognet i 20 Aar; foruden Ophold fik de Ildebrændsel og et Pengebeløb, men maatte da ikke tigge. Ved deres Død arvede Fattighuset deres Efterladenskaber. Meldte ingen Kvinder sig, udlejedes Stuerne, og eventuelt Overskud blev sat paa Rente. Hvert Aar lavede Præst og Medhjælpere et Overslag over Indtægt og Udgift for Fattigvæsenet og Skolen, der efterhaanden dreves under eet; det tilstilledes derefter Patronen paa Trøjborg og Herredsfogden til Godkendelse. Beboerne paalignedes saa, hvad hver skulde give af Rug og Malt (til Brød og Øl) samt Klæde, desuden et Pengebeløb. Fattigbøssen, der gik rundt ved Bryllupper, og Klingpungen i Kirken gav ligeledes deres Bidrag, og fra Schackenborg modtog man lidt Legatpenge, saa Kassen nok kunne være i god Orden. 1730 indeholdt den $60 \mathrm{Mk}$. lybsk + $100 \mathrm{Mk}$., skænket af Vedel selv.

Man vil af ovenstaaende se, at Vedel, der 1722 blev Provst, har været som en Høvding i sit Sogn, og han har utvivlsomt 
følt sig som saadan. Han talte villigt Smaafolks Sag overfor deres Herskab, men paa den anden Side ordnede han helst alt efter sit eget Hoved uden synderlig Hensyntagen til andre, ligesom han ønskede, at alle skulle vise ham den ham tilkommende Skyldighed. Derfor var det kun naturligt, at han med de andre Præster klagede over de Bønder i Lø Herred, der før 1713 havde hørt under Holsten-Gottorp og derfor siden vægrede sig ved at svare deres Afgifter til Gejstligheden, som de skulde. Sagen gik i Orden, hvorledes vides ikke.

Som Prædikant har Vedel som mange andre pietistiske Præster antagelig forkyndt et stærkt lovpræget Evangelium, men samtidig har han ved sin overlegne Personlighed formaaet at fængsle og tiltale sine Sognebørn, saa de gerne hørte ham, hvad den stigende Tilslutning til Gudstjenesterne jo ogsaa vidner om.

Fra 1722 har man et Brev fra Vedel til Aug. Herm. Francke, ${ }^{\text {97) }}$ hvori han beretter om Forholdene i Døstrup, og som ikke er uden Interesse ved de Oplysninger, det giver om det Vækkelsesarbejde, han og hans Sønner tog Del i. Den fromme Fader i Himlen, skriver han, lægger stadig en Sjæl efter en anden til den lille Hjord, men Præsterne, der skulde været Omvendelsesprædikanter („Bekehrer“), er i Stedet Forførere (,Verkehrer") og larmer mod de falske Profeter fra Halle, og mens de før ikke har kunnet bede en Bøn paa 4 Ord, holder de nu lange Bønner mod os og Evald i Højst, som om vi er Kættere, der vil indføre en ny Lære. I Døstrup har Guds Ord vundet god Indgang; der uddeles mange Ny Testamenter, saa han paa sin egen Bekostning nu vil lade flere trykke i Kobenhavn, og han og hans Broder $^{28}$ ) katekiserer i Landsbyerne Søndag Eftermiddag til stor Glæde for Folk. I Laurup samles alle hver Aften og synger et Par Sange af den hallensiske Salmebog, oversat paa Dansk, hvorefter der læses et Stykke af „.Den sande Kristendom". Tilsidst synges en Salme, og saa gaar alle hjem. (Jf. S. 33). En gang ugentlig er han i alle Landsbyerne, hvor de, der vil, kan tale med ham om deres Sjæle, og hvor han syn- 
ger og beder med dem. Nabopræsterne beder derimod fra deres Prædikestole om, at slige Tilstande aldrig maa findes hos dem, skønt Menighederne ofte ønsker det og taler om, at det kommer an paa, at de lever og lærer bedre.

En god Støtte havde Vedel i sin Søn Søren, der havde studeret i Kiel og Jena og som omtalt blev sin Faders Kapellan 1722. Ogsaa Degnen, Ludvig Pedersen, stod ham trofast bi; ved hans Død 1723 sagde Vedel bl. a. i sin Ligtale over ham: „Jeg har ingen, der saa oprigtigt vil bære Omsorg for, hvad eder angaar, thi de søger alle deres eget, ikke hvad der er Christi Jesu. Som Sønnen sin Fader har han tjent mig i Evangeliet."

1735 trak Vedel sig tilbage fra Provstestillingen, og to Aar efter døde han. Biskop Anchersen talte ved hans Baare over den af ham selv opgivne Tekst, 2. P. 1, 12-15. Fra hans senere Tid stammer et Par Optegnelser i hans Alterbog, der fortæller, hvilke Tanker der har besjælet ham. 27. S. e. Trin. staar der saaledes (i oversættelse):,Jeg har gjort, hvad jeg har kunnet; jeg har kunnet, hvad du, Kristus, har givet. Hvis jeg har sagt noget godt, er \#ren, Kristus, din“. Skærtorsdag: „Kristus er mig saa nærværende, som havde han denne Time udgydt sit Blcd, “29) og 3. Søndag efter Hellig tre Konger: 2. Kor. 12, 9: "Derfor vil jeg helst rose mig af min Skrøbelighed."

Søren Vedel ( $\dagger$ 1754) blev sin Faders Eftermand og vandrede troligt i hans Fodspor, dog uden at naa op paa Siden af ham. Han virkede iøvrigt for de unges Oplæring og katekiserede flittigt, om Sommeren hver Søndag Eftermiddag i Kirken eller Præstegaarden med Gennemgang af en af Davids Salmer og et Stykke af Lærebogen. „Herren, den trofaste, har ikke ladet den ringe Sæd hidtildags være uden Frugt og Velsignelse“, skrev han 1740 til Biskoppen, „formoder og, at den Gerning, som sker i Gud, vorder og hos nogle til en Livs-Lugt til Livet" ${ }^{30}$ ) I Yderbyerne samlede han ligeledes Folk, "og er dertil de gamles og de unges Begærlighed ret stor." Konfirmationen indrettede han noget efter de lokale Forhold, idet en Del af 
de unge skulde til Søs og derfor maatte have deres Præstegang afsluttet forinden. Konfirmanderne var i Reglen i Alderen 17-18 Aar; blandt dem havde han engang en af Sognets Skoleholdere.

Udpeget af Herredspræsterne blev Søren Vedel 1741 Provst for Lø Herred, skønt han, som han skrev til Biskoppen, kun med „sværmodigt Sind" overtog dette Hverv, især fordi man dermed let indvikledes i Processer, der voldte Uro hos en enfoldig Kristi Efterfølger, og han betingede sig at maatte frasige sig det, om Byrden blev ham for stor. I det hele taget var han en Fredens Mand, en Israelit uden Svig, hed det om ham i det Vita, der blev oplæst ved hans Begravelse. Han „søgte ikke med Lovens forfærdelige Trusler, men med Jesu søde Kærlighed og blodige Forsoning at bevæge de onde og genstridige og at smelte deres genstridige og haarde Hjerter til en sand og grundig Omvendelse og Tro til Gud." Karakteristisk for hans mildt pietistiske Stade er hans Kirkebøn 1751 i Anledning af Kvægsygen, som han vel ansaa som en Tugt for Folkets Synder, men dog kommende fra Guds faderlige Hjerte, der aldrig vil Mennesker noget ondt. Mange frygter ikke hans Vrede, men vi vil bekende vore Synder og bede om Forbarmelse over de Steder, hvor Soten er begyndt, og om, at den ikke maa smitte.

Vedel gik ofte paa Husbesøg og holdt Bedetimer med sine Sognefolk, og det siges, at han udrettede meget til Sjæles Opbyggelse og Frelse. Man forstaar derfor, at Biskop H. A. Brorson var glad for at visitere hos ham og f. Eks. 1744 kunde tale om den "kønne Opvækkelse“ hos ham. At den herrnhutiske Emissær Zeiler, der et Par Aar efter var i Døstrup, ${ }^{31}$ ) kun fandt 6 troende i Sognet, lyder derfor meget mærkeligt, men hænger vel sammen med det antipietistiske Stade, hvorudfra han har set Forholdene. Hans Dom over Vedel er ogsaa uretfærdig, naar han kalder ham „en gammel Luskepeter (Schleicher), hverken Ven eller Fjende." Naar det 1753 om en Mand og en Kvinde kunde siges, at hans Død var som Guds Hus og Himlens 
Port, og at hun sang et sødt Halleluja i Liv og Død, maa det tages som et Vidnesbyrd om et aandeligt Liv paa Stedet, som han har formidlet eller dog været med til at holde vedlige.

Personligt stod Vedel i det bedste Forhold til sine Sognebørn, og han udviste stor Gavmildhed mod Smaafolk, ofte over Evne. Som Kapellan havde han betalt Underhold for en forældreløs Dreng.

Ved hans Begravelse talte Brorson over ham ud fra Mt. 24, 21: „Vel de gode og tro Tjenere .... og formanede ud fra Hebr. 13,7: „Kom eders Vejledere i Hu“ Menigheden til at mindes de Mænd, der havde forkyndt Guds Ord for den, betragte deres Udgang og efterligne deres Tro.

Efter Søren Vedel blev hans Svigersøn Johannes Peter Brorson Præst i Døstrup (1754-91). Han blev „født Kl. 7 om Morgenen d. 1. April 1726 til denne elendige Verden" i Bedsted Præstegaard som Søn af Nicolai Brorson. Hans Huslærer gav ham Smag for Guds Ord, "saa jeg erfarede dets guddommelige og saliggørende Kraft i min Sjæl, som blev indtaget af min Frelsers Jesu søde Kærlighed, i hvilken jeg endnu ønsker at leve og dø." Vaagnede de om Natten, holdt de Bøn, spillede paa Harpe og sang et Par Salmer, inden de atter lagde sig til at sove. Hans Opdragelse har altsaa været helt i pietistisk Aand; senere var han en Tid hos sin Farbroder Oluf Adolf, der var Præst i Hilierslev i Thy og ogsaa sluttede sig til Bevægelsen, ${ }^{32}$ ) saa det kun var naturligt, at hans Virksomhed i Døstrup var præget af den.

Iøvrigt var han ingen stor Aand, noget sentimental, hvad hans ovenanførte Ord jo ogsaa viser, og som Personlighed kunde han ikke maale sig med nogen af sine to Forgængere i Embedet. Men han gjorde et trofast Arbejde baade i og udenfor Kirken, og hans Minde levede længe efter ham. Hertil bidrog sikkert hans store Venlighed og Gavmildhed. Sine Folk havde han længe, og han var ikke ræd for at aabne sit Hus for hjælpeløse; et Par fattige Folk, som ingen vilde have, var saaledes hos ham i 3 Uger, til Øvrigheden fik dem anbragt, 
og en tidligere Hoffurer boede ikke mindre end 19 Aar i Præstegaarden. Hans Farbroders Salmer lød dagligt i hans Hjem, og selv havde han en lille poetisk Aare; til sin Embedsbroder Hieronimus Clausen skrev han et Digt, da hans Hustru døde. Nævnes maa det ogsaa, at han stod i det bedste Forhold til Herskabet paa Trøjborg; en Datter lod han opkalde efter Grevinde Ida Hedvig Moltke, f. Buchwald, og hun paa sin Side skænkede 1763 en Kalk til Kirken.

Mens det takket være navnlig Pastor Jørgensens udføriige Sognekrønike er muligt at faa temmelig god Besked om Forholdene i Dostrup, stiller Sagen sig anderledes, naar man vender sig til de andre Sogne, hvorfra der i det hele taget kun foreligger ret sparsomme Oplysninger. Brorsons kortfattede Visitatsrelationer til Kirkekollegiet og nogle - alt for faa og ufuldstændige - Indberetninger fra Provster og Præster til Biskoppen er det eneste Materiale, man faktisk har at bygge paa, saa man langtfra faar Underretning om alt det, man kunde ønske at vide, thi de herrnhutiske Emissærers Optegnelser om Forholdene i Menighederne maa benyttes med en vis Varsomhed, da Forfatterne tidt kan være saa uvilligt stemt mod alt pietistisk Væsen, at deres Domme bliver uretfærdige (jf. foran Zeidler om Søren Vedel). Det tør derfor heller ikke ventes, at det Billede, der nedenfor skal forsøges tegnet af den nordvestslesvigske Pietisme, bliver saa fuldkomment, som det kunde have været, om Kilderne havde flydt rigeligere. Det er begrænset, hvad der kan fortælles om dens ledende Mænd, de Præster, der søgte at føre Vækkelsen ind over deres Sogne, og hvad de udrettede, ligesom det ogsaa i høj Grad maa beklages, at der findes saa lidt Stof til Bedømmelse af, hvorledes Befolkningen i Almindelighed stillede sig til det nye Røre.

Fra Aarene 1745, 1746 og 1747 foreligger der Indberetninger fra Provst Søren Vedel om nogle Visitatser i Lø Herred. ${ }^{33}$ ) Han er, siger han, vel tilfreds med Præsterne, "de kære Mænd“: og deres Prædikener, om end „Maaden at behandle, fremsætte og an- 
vende ${ }^{(34)}$ ) er en Del forskellig. Ungdommen har svaret vel, saa. der er arbejdet godt med den, og det kan ventes, at der af den grønne Sæd i Fremtiden maa komme flere Frugter til Kristi Naades Riges Udbredelse. Bedst var den i Mjolden, hvor den kunde svare ud fra Bibelen og Sagernes rette Grund med Forstaaelse, saa der af Præsten var virket med en gudelig Retsindighed og Nidkærhed.

I Mjolden var Broder Brorson, den senere Biskop i Aalborg, Præst 1722-36, og det er sikkert ham, der ved sin varme og evangeliske Forkyndelse formidlede en Vækkelse paa Stedet. Noget nærmere kan ikke siges, men at han har formaaet at tale Folk til Hjerte, fremgaar af de Bemærkninger, Christian VI nedskrev, da han efter at være udnæunt til Biskop. 1737 prædikede for Kongen: „Endnu har ingen saaledes udlagt Teksten om de ti spedalske. Han har rørt vort Hjerte. Han er et udvalgt Redskab i Guds Haand, og det er næsten Skade med Hensyn til hans Prædiken, at han skal være Biskop, thi saa har ingen Nytte af den Gave, han har til at prædike ..... Ak, jeg er uren og har Renselse behov. ${ }^{\text {(85) }}$ )

Han efterfulgtes af sin Fætter, Joh. Hieronimus Clausen fra Løgumkloster (Trøjborg). Ogsaa han var Pietist med Eksamen fra København 1736, saa han maa have opholdt sig i Hovedstaden under de stærke kirkelige Brydninger derovre i Aarene forud. At han fik Embedet straks, skyldtes vel, at Ejeren af Trøjborg, Buchwald, havde Kaldsret til Mjolden. Men for Resten har han utvivlsomt været en nidkær Mand i sit Sogn, og hans Svoger, Biskop H. A. Brorson, har sikkert haft Ret, naar han ved sin Visitats 1743 karakteriserede ham som en retsindig og flittig Sjælesørger. Han prædikede ved den Lejlighed over Troens Forhindringer; Børnene svarede til Fornøjelse, og Menigheden var "særdeles bevægelig." 1740 indberetter han om sine Katekisationer, at han overhører i sine Prædikener, og at han om Sommeren Søndag Eftermiddag atter samles med en Del af Menigheden i Kirken, hvor han da igen katekiserer baade med 
linge og gamle. Sidste Vinter lagde Vejret Hindringer i Vejen, men ellers plejer han efter Gudstjenesten at gennemgaa Katekismen med dem, der bliver tilbage. ${ }^{36}$ )

Hvor megen Indflydelse han fik i Sognet, er ikke helt let at afgøre. Zeidler siger, der var 10 vakte, men at de var meget lovprægede og pietistiske, ligesom Præsten selv var fuld af Angst og Uro, et Vidnesbyrd om at hans Forkyndelse har haft den strenge Bodsprædikens Karakter. ${ }^{37}$ ) Hans Eftermand Hans Schau (1754-58) var Student fra Altona og havde læst i Halle, inden han 1751 tog Eksamen i København. Han har sikkert ogsaa virket i pietistisk Aand, thi 1757 konstaterer H. A. Brorson, at der endnu er Vækkelse i Sognet, og muligt har han bedre end Clausen vidst at tale evangelisk til sine Sognefolk. Ved Biskoppens Besøg 1763 omtales der ingen Vækkelse, men Ungdommen svarede vel.

I hvad Aand Hans Adolf Brorson som ung Præst virkede i sit Fødesogn Randerup (1721-29), behøver ingen nærmere Forklaring, men det er vel værd at understrege, at hans Forkyndelse har været af en helt anden Art end Clausens. Dette fremgaar af et Brev fra den pietistiske Præst Ambders paa Helgoland til hans Broder Nic. Brorson, thi han erklærer deri, at han er enig med Hans Adolf $i$, at Bodsprædiken ikke gør Sagen klar, men at Jesus Kristus ogsaa ret maa fremstilles for Sjælene, og at dette sker kun ved Forbarmerens Rigdom eller kort sagt ved Evangeliet, thi ellers vil der ingen Fornyelse blive. ${ }^{3 *}$ ) Man ved forøvigt ikke noget om hans Arbejde i Sognet, men der er al Grund til at tro, at han har haft Indflydelse paa dets aandelige Udvikling, og at den Vækkelse, han 1753 omtaler som forhenværende, kan føres tilbage til ham selv. Hans Efterfølger og Svoger, Jens Hygom (1729-63), en Broder til Aarhusbispen, fik ved Visitatsen 1743 det Skudsmaal, at han var en retsindig og ustraffelig Mand, der gjorde sig megen Umage med Ungdommen. Han prædikede om Ægtefolks Pligter mod Gud, hinanden og deres Børn. De fleste i Menigheden levede ustraffeligt og havde tilstrækkelige Kundskaber i deres Børnelærdom. 1753 
var adskillige af de tilstedeværende særdeles bevægede, men om noget Røre høres der som sagt ikke. Hygom har formodentlig, sin gode Vilje til Trods, ikke været i Stand til at øve samme Indflydelse som Brorson. Fra herrnhutisk Side siges der dog, at der var nogle vakte, blandt dem Degnen. ${ }^{34}$ )

Jens Gregersen, født i Døstrup 1677 og Præst i Visby 1701 — j4, skylder sagtens Nissenius Vedel sin Opvækkelse. Han virkede med stor Nidkærhed i sit Sogn og fik det Vidnesbyrd, ${ }^{40}$ ) at han var "et skinnende og brændende Lys i sin Menighed, et Mønster paa en retsindig Præst", og at Sognet ved ham mærkeligt tiltog i Gudskundskab. Hver Søndag katekiserede han over sin Prædiken og Katekismen, ligesom han om Lørdagen overhørte Nadvergæsterne før Altergangen næste Dag. Da Nissenius Vedel trak sig tilbage som Provst, henledte han Opmærksomheden paa Jens Gregersen, som derpaa af de andre Herredspræster blev kaaret til hans Eftermand. Jens Schau, der blev udnævnt til Præst i Visby 1754, byttede imidlertid Embede med Clausen fra Mjolden, scm nu virkede her til 1778, fra 1763 ogsaa som Provst for Lo Herred. ${ }^{41}$ ) I Visby șkete der den Forandring med ham, at han under herrnhutisk Paavirkning kom fri af $\sin$ lovprægede Livsanskuelse og derved blev i Stand til at være til aandelig Hjælp for flere, saa der siges at være blevet en Del vakte paa Egnen. Hans Eftermæle blev, at han var en god og venlig Mand; de fattige lod han faa Andel i sit Offer. 1759 fik han en Søn af Provst Søren Vedel, Nissenius Vedel, til Kapellan; han havde studeret baade i Halle og Kabenhavn, hvorved hans Stade turde være antydet. I Degnen og en Kromand i Sognet havde han ligeledes god Stotte.

Zeidler yndede ikke Fr. Dan. Blechingberg i Ballum (1732 -65), men han modarbejdede ogsaa Brødremenigheden. Paa den anden Side synes han at have været en nidkær Præst, der bl. a. tog sig ivrigt af de unge. Paa samme Maade som de ovenfor nævnte gejstlige gjorde han meget ud af Katekisationen; med de større Børn gennemgik han Afsnit af Pontoppidans Forklaring og fik dem til at svare ogsaa med deres egne Ord; ide smaa 
lærte Katekismen, som de kom igennem flere Gange om Aaret. En Katekisation plejede at vare henved 2 Timer..') Maaske under Paavirkning fra Dostrup fik han 1737 en fast Ordning paa Fattigvæsenet, som tidligere kun havde sine Indtægter gennem Kirkebøssen, Klingpungen og frivillige Gaver. Nu fik han ved et Møde i Kirken Folk til at tegne sig for bestemte Bidrag, og det blev til saa meget, at man det første Aar kunne understøtte 35 indskrevne trængende. ${ }^{43}$ ) Ved sin Visitats 1744 nævner Brorson en Vækkelse, men 10 Aar senere omtales den som forhenværende. Den var blevet ledet af en Urmager. For Resten var Biskoppen tilfreds med Skolevæsenet, og han havde intet at udsætte paa Degnen. 1750 maatte han derimod paatale den efter hans Mening usømmelige Fastelavnslystighed paa Egnen.

1712-44 var Joh. Claudius (Clausen) Præst i Emmerlev; hans Fader, Bedstefader og Oldefader havde før ham, lige siden 1598, været Ihændehavere af Embedet. Han havde studeret i Leipzig og var gift med en Datter af Provst Reimarus i Tonder saa hans kulturelle Standpunkt har vel nærmest været tyskpræget, og han har maaske selv været moderat Pietist. Som Provst for Møgeltønder Herred svarede han 1738 paa sine Præsters Vegne Kirkekollegiet, ${ }^{44}$ ) at dets Ordre om Husbesøg skulde med underdanigste Horsomhed under Guds medarbejdende Naade blive efterkommet, men man ønskede flere Medhjælpere til Indseende med de uskikkelige, saa Præsterne efter Advarsel kunde ekskommunicere dem. Dog maatte dette ikke faa Skin af at være en Straf, de skyldige skulde forstaa, at der laa Kærlighed bagved. Men forøvrigt fandt man Spørgsmaalet cm en kirkelig Disciplin saa vanskeligt, at man ikke selv turde fremkomme med noget Forslag, men kun ønskede, at en eventuel Nyordning maatte blive til Guds Fre og til Kirkens Opbyggelse. 1744 nævner Brorson en Opvækkelse i Sognet; den kan muligt føres tilbage til Kapellanen Jens Clausen fra Ribe, der var blevet Kandidat 1731 og $1739-59$ var adjungeret Embedet. 
Joh. Claudius efterfulgtes af Laur. Gram (1744-57), der ligeledes var Provst. Brødremenigheden havde da faaet nogen Indgang, 1748 nævnes et Samfund paa 14, og 1744 var en Kvinde hemmeligt rejst til Herrnhut. Gram forespurgte da i Ribe, om hendes Ejendele skulde konfiskeres, men Biskoppen svarede, at der intet kunde foretages mod hende, da hun var udvandret for Forordningen 1745 derimod. 1753 udtrykte Provsten Ønsket om, at der i Loven maatte komme et direkte Forbud mod herrnhutiske Forsamlinger. ${ }^{45}$ )

1751 var Brorson atter i Emmerlev, hvor han udtalte sig rosende baade om Gram og Clausen for deres Flid, især med at besage de syge. Aaret efter anbefalede han overfor Kirkekollegiet varmt den sidste til Forflyttelse. ${ }^{46}$ ) Kirkegangen i Sognet var god: ved Visitatsen var der "som ellers altid“ saa mange til Stede, at Brorson næppe kunde røre sig ved Alteret, men Forsøg paa at faa Kirken udvidet var mislykkedes. En Entreprenør havde forlangt $24.000 \mathrm{Rdl}$. for Arbejdet, hvad Grevinden paa Schackenborg fandt for meget, saa hun foreslog i Stedet at lade afholde to Gudstjenester om Søndagen. Men dette afviste Biskoppen, da det efter hans Formening vilde føre til Forvirring.

Hvor stor Tilslutning Enevold Evald havde faaet i Møgeltønder. kan ikke siges, men senere var en Kaptajn Naamann Leder for en Gruppe vakte, som desuden havde en god Ven i Præsten Godske Møller (1730-41), der samlede mange om sin Prædikestol. Derimod var Christoffer Schultz (1742-56) Modstander af Brødremenigheden, „en Vindmager“, siger Zeidler, der iøvrigt opgiver Antallet af vakte til 16. En paatænkt Kirkeudvidelse strandede ogsaa her paa Grevindens Modstand; hun undskyldte sig baade med sin Gæld og Vanskeligheder ved paa Grund af Kvægsygen at faa Materialer hentet, senere vilde hun derimod gerne hjælpe til med at sætte Kirken i Stand. ${ }^{47}$ )

I Daler mærkedes Pietismens Indflydelse tidligt gennem den nidkære Provst Anders Vedel $\left.(1705-30)^{44}\right)$, ,en sand Jesu Tjener" kaldte Herrnhuterne ham. $\left.{ }^{19}\right)$ Da han hurtigt indførte Kon- 
firmationen i Menigheden, klagede Bonderne 1708 over disse nye Skikke og Paafund, som de fandt upaakrævede. Han forlangte en ny indført Lærebog kunnet af de unge, og ved Undervisningen indskærpede han dem bl. a. at lyde ham mere end deres Forældre, da de modsat ham kun var i Stand til at vejlede dem i det timelige. Paa Konfirmationsdagen lod han dem efter Afhøring for Alteret med oprakte Fingre sværge at ville holde "nogle Poster", hvorpaa han med Haandslag sagde til dem: „Annam den Helligaand!“ Yderligere ankede de over hans strenge Kirketugt og haarde Domme, og de mente, han var for krævende med Hensyn til Offer.

Den daværende Provst, Junghans i Møgeltønder, vilde gerne mægle. Vedel forsvarede sig med de unges Uvidenhed, som skyldtes, at de baade forsømte Katekisation og Skolegang til Fordel for Knipleriet; derfor havde han efter Samraad med nogle velsiridede indført Støckens Lærebog -- hans Formand brugte en haandskreven - men nogle vilde ikke købe den. Han indrømmede, at han forlangte, at de skulde have grundigt Kendskab til deres Saligheds Sag, før han tog dem til Alters, men Konfirmationen var en oldkristelig Skik, og han havde drøftet dens Indførelse i Forvejen med Grevinde Schack, der ligefrem havde befalet ham baade at cverhøre Børnene og kræve et Løfte af dem.

Trods Bondernes Uvilje kom det til et Forlig, men da Sagen var indgaaet til Biskoppen, lod den sig ikke standse. Paa Landemodet advarede han $i$ et Monitum Præsterne mod at støde deres Menigheder ved nye Ritus mod deres Ed og Embedspligt og ikke overmodigt at gøre deres Sag til Guds, og da desuden foretagne Vidneafhøringer ved Møgeltønder Ting syntes at bekræfte Bøndernes Klager, beordredes en Provsteret nedsat til at bedømme Vedels Adfærd.

Dennes Forhandlinger kendes ikke, men d. 20. Juni 1709 udtalte Landemodet i Ribe, at da Vedel afbad sine Forseelser, og Provsten gav ham et godt Vidnesbyrd og gik i Forbøn for ham, 
og der desuden var sluttet Forlig med Bønderne, vilde man nøjes med at idømme ham en Bøde paa $30 \mathrm{Rdl}$. til de fattige og 4 Rdl. i Sagsomkostninger. Men ved Siden af fik Præsten et skarpt Paalæg om ikke at indføre nye Skikke i Kirken og at forholde sig med Sagtmodighed efter sin Ed og sin Pligt.

Konfirmationen blev derefter stillet i Bero. Den indfortes først igen c. 1735 .

Om Vedels senere Færd kan intet oplyses, men da hans Eftermæle var, at han havde været „en nidkær Mand til Guds Ere, hvis Ihukommelse mange her i Sognet er udi Velsignelse“, maa han efterhaanden være kommet paa en god Fod med Beboerne. At han med Aarene er blevet mildere, fremgaar ogsaa af Herrnhuternes føromtalte Karakteristik af ham. Zeidler siger, der var 16 vakte i Scgnet, men om de har haft nogen Forbindelse med Vedels Virksomhed, vides ikke. En Provstevisitats i 1740erne giver ingen særlige Oplysninger om Forholdene udover, at der var mange i Kirke og god Hørelyst, samt at Ungdommen var vel oplyst.

I Agerskov, Nr. Rangstrup Herred, ${ }^{51}$ ) havde allerede Præsten Chr. Riese (1696-1747) været venligt sindet mod Pietismen. Han lod sin Søn Otto studere baade i Kiel, Jena og København og førte selv en kraftig Kamp mod Ligvagt, Fastelavnsløben o. desl., men det var dog først, da den unge efter i 7 Aar at have været Huslærer hos Grev Holstein 1729 kom hjem og blev sin Faders Kapellan, at der ret kom Gang i Arbejdet. Han gjorde flittigt Husbesøg, holdt Søndag Eftermiddag gudelige Forsamlinger, især for syge og svage og viste $\mathrm{i}$ det hele taget stor Aktivitet i Sognet, saa Banden, Sværgen, Krogang og Julestuer næsten helt forsvandt. Herrnhuterne vandt imidlertid ogsaa nogen Indgang, men skønt Riese ansaa mange af dem for at være redelige Folk, forstod han dem ikke. Han foretog derfor med nogle andre en Rejse til Oldesloe og Pilgerruh for dér at lære dem nøjere at kende; flere traf han i Hamborg og Altona, blandt dem adskillige redelige, men ogsaa en Del, der var 
hildet i sværmeriske Anskuelser. Megen Vanskelighed havde han hjemme med Separatisten Jens Brock, der midt i 1740erne kom til Sognet og var nær ved at forvilde nogle i Menigheden, men da han saa løb bort med en Pige fra S. Løgum, lagde Røret sig."i)

Otto Riese, der blev sin Faders Eftermand (1747-79) og Herredsprovst (1749) var meget skoleinteresseret, og det lykkedes ham at faa en $4-5$ Skoler bygget i Provstiet, men Lærerne var ikke gode, da Bønderne vilde have de billigste. Det vil sige, at han ogsaa mødte Modstand. 1738 klager han til Kirkekollegiet over det grasserende Helligdagsarbejde, som den ringe Mulkt ikke formaaede at hindre, og over, at Medhjælperne af Frygt for deres Naboer kun ydede ham ringe Støtte, men det var ogsaa svært at finde ret mange, der virkelig var „Mænd i Kristus“. Han onsker i det hele, at en retsindig Præst maa faa større Myndighed, og at Kirkedisciplinen maa skærpes, saa længe Synden er saa stcr, omend Betingelsen for at anvende den efter den første Menigheds Eksempel maa være, at de retfærdige Tal "provalerer" blandt os. ${ }^{\text {85 }}$ )

1750 omtaler Brorson en „Hejlig Vækkelse“ i Sognet, men 1766 erklærer Riese selv, at den er i Tilbagegang. Almuen nu it overtroisk og drages mod Vantro og Fornuften, og den store Flok tænker paa at opfylde deres Hjerters Begæringer, hedder det igen $1771 .^{53}$ ) En af Grundene har vel været Præstens lovmæssige Tale, der nok kunde ruske Folk op, men mindre var i Stand til at vejlede dem i det daglige. Hermhuterne mente endog, han i mange Aar var uomvendt, og han var heller intet for de 20 af deres Venner i Bovlund, som mest maatte søge til Fræster andetsteds. Imidlertid skete der en Forandring med ham, efter at han var kommet i Forbindelse med Christiansf $\in$ ld, og han blev mildere stemt mod Brødrene. ${ }^{54}$ )

Paa Opfordring af Rektor Falster og H. A. Brorson, der som sin Broder i Aalborg var Svoger til Riese, oversatte han Gottholds „400 Andagter ${ }^{(\overline{\bar{\alpha}})}$ ) til Dansk, men da de allcrede var blevet trykt i Flensborg, udkom de ikke i Bogform. 
I sin Fritid syslede han med mekaniske og fysiske Forsøg, og med sin Nabopræst P. Gutfeld i Bevtoft vekslede han under pseudonymt Mærke flere Stridsskrifter, hvori han forsvarede det kopernikanske Systems Rigtighed.

Chr. Outzen i Toftlund (1723-58) havde studeret i Jena, og Brorson roser ham 1742 for hans Alvor og siger, at hans Ungdom, der før var "ekstrem" vankundig, nu svarede dejligt. Før sin Død, fortæller Biskoppen, holdt han en gribende Prædiken, gik derpaa hjem og til Sengs for ikke at rejse sig mere. I Kirkebogen skrev han: „O søde Frelser, Jesus, lad os samles for dit Ansigt i evig Glæde, Herlighed og Salighed hos dine kære Engle" og derefter en lang Bøn. ${ }^{5 t}$ ) Det synes dog ikke, at han formaaede rigtig at slaa igennem $i$ Sognet, thi ved Visitatsen 1762 maatte Brorson erkende, at der ikke var den Frugt efter ham, man skulde have ventet. Hvorvidt de 20 vakte, Zeidler melder om, kan henføres til hans Forkyndelse, faar staa hen.

I Gram Herred ${ }^{57}$ ) ses Pietismen ikke at have vundet nogen Indgang. I Nustrup byggede den velstaaende Provst Lauge Vedel (1692-1733 et Fattighus for Værdien af en Guldkæde, hans Hustru skænkede, men om hans Forhold til Tidens Rørelser vides intet. Særlig paaskønnet var hans Gave ikke; ingen vilde bo i Huset, der derfor blev udlejet og tilsidst helt forfaldt.

Et Spørgsmaalstegn maa der vist sættes ved den Pietisme, Skoleholder Nis Heinsen gav Udtryk for, da han 1748 og 1749 søgte Stilling hos Brorson, først i $\varnothing$. Linnet, siden i Gram. Han havde ført en omflakkende Tilværelse, men maatte tilsidst, skrev han, Juleaften 1747 overgive sig til Guds forbarmende Naade, hvorved han fandt en stille Kraft til at overvinde Synden og til at digte en Salme, saa „Biskoppen kan fornemme, hvad Salighed mig er vederfaret". Et Par af de 6 Vers lyder:

Nu vil jeg mig henvende i Troen paa Guds S $\phi \mathbf{n}$ og rent ud bekende med ydmyg Suk og Bфon, at jeg har ham bedrøvet med Vantros store Synd og har den længe $\emptyset$ vet og lagt udi det Dynd. 
- O, hvor mig er tilmode, jeg fundet har min Skat, Guds S $\not \mathrm{n}$, det som de gode i Troen haver fat. Jeg vil ham ikke slippe $f \not r$ han velsigner mig. jeg bygger paa den Klippe, nu og evindelig.

Efter et Svar, Brorson gav ham under et Foretræde: „Om Gud vil hjælpe, sker det enten hos den ene eller den anden,“ ser det ikke ud til, at Biskoppen har vurderet ham særlig højt.

Den store Vækkelse i Hygum, Frøs Herred, i 1730erne skal ikke omtales nærmere her, da den i sit Forløb er nøje forbunden med det samtidige Røre i Ribe; desuden er den skildret andetsteds. ${ }^{58}$ ) Derimod kan det have sin Interesse at vide, at dens drivende Kraft, P. Jacobsen Hygom, der 1718-32 var Kapellan og Sognepræst i Lintrup, som det ses af hans liber daticus, fra Begyndelsen har fulgt den fra Stiftsstaden udgaaende Bevægelse med megen Opmærksomhed..$^{59}$ ) Han var sikkert allerede da pietistisk vendt, men uden at være kommet til nogen Afklaring, hvad vel ogsaa hans Salme „Jesus din søde Forening at smage" kunde tyde paa, og det vides da heller ikke, at hans Virksomhed i Lintrup dengang bar nogen Frugt. Det er først i Hygum (1732-36), der er sket en Forandring med ham, efter at han var kommet i nærmere Forbindelse med Ribefolkene, og det tør vel saa formodes, at den Vækkelse, der nu omtales i hans gamle Pastorat i Aarene før 1737, kan henføres til ham. ${ }^{\text {s0 }}$ )

Forholdene i Skærbæk, Hviding Herred, turde være betegnende for den Udvikling fra Pietisme til Herrnhutisme, der saa mange Steder fandt Sted. Her kom Sognepræsten, Bøgvad (1724-41), i den heftigste Strid med sin Degn og Kapellan, Mikkel Stilling (1725-49), der var Pietist, og hvis voldsomme Optræden i 1730erne nok kunde tyde paa en Paavirkning af den samtidige, halvseparatistiske Vækkelse paa Ribeegnen. Han holdt gudelige Forsamlinger ude i Sognet med Sang, Bøn og Læsning, hvilket „efter Ritualet og Loven ikke uden udi Kirken og for den offentlige Forsamling af en Præst burde trakte- 
res", ligesom han efter Bøgvads Skøn lærte uforstaaeligt og søgte at forlede de enfoldige, især Ungdommen, til tvivlsomme Meninger. Sin Sognepræst negligerede han fuldstændigt, ja han angreb ham endog engang i selve Kirken under en af hans Katekisationer med saa stærke Ord, at Præstekonen besvimede (!), og Menigheden kom i Oprør. Ikke sært, at Bøgvad beklagede sig over ,at „Mandens Ondskab daglig tiltager“, og at han, da der ogsaa personligt var mange Rivninger mellem dem, anskede en Provsteret nedsat til Vurdering af Stillings Forhold. Denne fik vel 1736 et Forlig i Stand, men skaffede ikke Ro, saa Sognepræsten 1738 besværede sig over, at hans Kapellan nu gik saa vidt, at han holdt Ekstragudstjenester Søndag Eftermiddag, naar han selv havde prædiket om Formiddagen naturligvis fordi han ikke anerkendte hans Forkyndelse.

Noget Tilløb maa Stilling aabenbart have haft; en anden Sag er det, at hans Metoder næppe har været gunstige for Udviklingen af et sundt aandeligt Liv paa Stedet, saa det var sikkert heldigt, at han bøjede sig for den nye Præst, And. Fog, der 1741 fulgte efter Bøgvad, og som før, da han var Hører i Ribe, afgjort havde sluttet sig til den strenge pietistiske Bevægelse i Byen. Hans kraftige Omvendelsesprædikener, der navnlig dvælede ved Menneskets Elendighed, var ikke uden Virkning, men det gik ham selv, som det gik saa mange andre af hans Meningsfæller, at han var $i$ indre Uro, fordi han ikke kunde $f ø l$ e den Fred, der efter hans egen Anskuelse var det sande Kristentegn. Han tænkte endog paa at nedlægge sit Embede og vilde ikke prædike, men et Medlem af hans Menighed fik dog sat Mod i ham, saa han fortsatte. 1743 fik Sognet Besøg af to herrnhutiske Emissærer, som han aabnede sit Hjerte for, og kort efter kom han i Forbindelse med deres sønderjydske Hovedkvarter i Stepping; derved lærte han ikke at bygge paa sine Stemninger og Følelser, saa han nu blev lysere af Sind og hans Prædikener virkelig evangeliske. ${ }^{(1)}$ ) Vækkelsen i Sognet tiltog derved yderligere, og der holdtes Møder i Præstegaarden et 
Par Gange ugentlig, hvor Mænd og Kvinder paa herrnhutisk Vis forsamledes særskilt; Fogs Søster ledede Kvinderne. Disse gudelige Forsamlinger, hvor ogsaa Lægfolk førte Ordet, var imidlertid de udenforstaaende en Torn i Øjet, og 1744 klagede 28 Mænd i Hjemsted med Farver Prætorius i Spidsen til Provsten over, at en Karl fra Skærbæk og nogle andre i et Aars Tid baade i Præstegaarden og i Hjemsted Skole havde talt og udlagt et "Sprog“ af Ny Testamente. Da dette baade var ulovligt og forargeligt, spurgte man, om ulærde Bondesønner havde Ret til noget saadant, thi i saa Fald bad de Provsten, at han "gunstigst behagede at forføje det saadan, at de maatte blive indsat i Menigheden som Lærere, at man kan vide, at de er af den gejstlige Øvrighed approberet." Der er utvivlsomt intet kommet ud af Klagen, da de paagældende naturligvis har haft Fogs Tilladelse, og Brorson har saa intet villet gøre ved Sagen. ${ }^{62}$ )

Men ogsaa efter sin Forbindelse med Brødremenigheden ønskede Fog at haandhæve en streng Kirketugt. En Konfirmand, der trods hans Forbud var gaaet til Julestue, blev 1751 afvist, uden at Fog vilde tage ham til Naade, da der skulle statueres et Eksempel, og han tvivlede om hans Anger; for Resten ansaa han Forældrene for at være mest strafskyldige.

Fogs Eftermand var Hans Raer fra Mjolden (1759-79). Han havde før været Hører i Aalborg, hvor Br. Brorson gav ham en god Anbefaling. Han var ikke „Broder“, men venligt sindet mod Herrnhuterne. ${ }^{63}$ )

Søren Vedel i Rejsby (1684-49), en Broder til Nissenius V. i Døstrup, maa vel ogsaa have været Pietist, siden hans Søn Niels (siden Præst i Værum ved Randers) studerede i Halle. Om hans Virksomhed vides ellers intet, men han har jo nok med Velvilje set paa det Vækkelsesarbejde, som hans Kapellan fra 1734 og senere Efterfølger Joh. Luffe $(\dagger 1752)$ udførte. Brorson paaskønnede ham meget og omtaler 1745 den kønne Opvækkelse i Sognet. Ogsaa Hermhuterne var glade for ham, skønt hans Kone var ikke omvendt, mente Zeidler, og de mindedes ham 
som „et tro Jesu Vidne“. For Resten var der kun et ringe Antal "Brødre“ i Sognet. Ved Luffes Død udbad 13 Sognemænd sig hos Biskoppen at faa en lige saa god og kærlig Sjælesørger. Hans Kapellan og Eftermand, Andr. Radoor (1753-94) kunde dog ikke udfylde hans Plads, og ved sin Strenghed korn han i Modsætning til mange. Allerede 1753 havde han en Strid med Beboerne, fordi han nægtede at tage to unge nykonfirmerede Sømænd til Alters før Mikkelsdag, skønt de skulde sejle ud; han vilde nemlig først se, hvordan de skikkede sig; og om deres Omvendelse var alvorligt ment, hvad han betvivlede. De unge rejste uden Altergang. Da Brorson visiterede lige efter hans Komme (1753), mente han om ham, at ogsaa han søgte sin Menigheds Salighed; Ungdommen var vel undervist. Men den tidligere Vækkelse synes aftaget, thi det hedder kun, at der endnu er nogle Sjæle, der tragter efter Himlen.

Allerede som Kapellan i Grejs ved Vejle (1742--46) havde Mt. Vind hos sin - senere - Svigerfader, Biskop Brorson, vundet Anerkendelse for det nidkære Arbejde, han udførte i Sognet $\left.{ }^{64}\right)$ og der er derfor heller ingen Grund til at tvivle om, at han i Brøns (1746-81) fortsatte i det samme Spor; han vedblev da ogsaa at staa i det bedste Forhold til sin Biskop. Men noget helt andet er det, om han har forstaaet at tage sin nye Menighed paa den rette Maade, idet han holdt en meget streng Kirketugt. Naar nogen gik for lidt $\mathrm{i}$ Kirke eller ventede for længe med at søge Nadveren, blev han afvist, naar han indtegnede sig til Altergang, og maatte da først udstaa det offentlige Skriftemaal, før han blev antaget;selv en gammel, sengeliggende Kone nægtede han af samme Grund at berette. Kirkekollegiet, hvortil der blev klaget, befalede ham imidlertid at betjene hende. ${ }^{65}$ ) 1754 blev han af Ridefoged Muusmand overfaldet med Trusler og onde Ord, fordi han havde skræmt hans Pige til i Præstegaarden at udlægge, hvem der var hendes Barnefader. ${ }^{6 v}$ ) Han har vist $i$ det hele manglet Bøjelighed og har haft Vanskelighed ved at gaa ind paa andres Tanker; derfor var det vel ogsaa, 
han stod Herrnhuterne haardt imod, var "en Fjende“, siger Zeidler, saa de faa, der var i Sognet, søgte til Kirkerne i Skærbæk og Rejsby. Naar Brorson paa en Visitats maatte trøste en melankolsk Kvinde, tyder det ligeledes paa, at Præsten ikke raadede over de milde Ord, hun trængte til at høre. Biskoppen fandt dog 1744 Ungdommen munter og en Del af Menigheden helt bevæget, men om nogen Vækkelse er der ikke Tale. 1757 prædikede Vind om Guds Børns Salighed med Hensyn til Troens og Levnedets Retfærdighed.

I Hviding prædikede ved Bispevisitatsen 1745 Provst Fog (1706-51) om tilbørlig Orden i Menigheden, hvilket gav Brorson Anledning til bagefter at tale om, hvad Forandring det gav, naar Paulus kom paa Besøg til et Samfund, noget, der foranledigede megen Bevægelse i Kirken. Om Vækkelse høres der dog ikke noget, derimod siger Biskoppen, at der har været en for en 7-8 Aar siden. Mere faar vi ikke at vide, men da en Pige fra Sognet var udvandret til Herrnhut, er det muligt, at den har været inspireret af Brødremenigheden. Senere blev der i Sognet en betydelig Kreds, der under Ledelse af Præsten Joak. Evald (1764-1807) sluttede sig til den; 1769 angaves dens Antal til 25.

At Henning Nissen i Højrup (1730-52) foruden i Kiel og Wittenberg ogsaa havde studeret i Halle, ${ }^{67}$ ) synes ikke at have gjort ham til nogen rigtig Pietist. I alt Fald fik han 1747 en skarp Advarsel, fordi mange Børn slet ikke gik i Skole, og nogle paa 14-18 Aar ikke engang kendte Bogstaverne. Han tilholdtes derfor at sørge bedre for Undervisningen og ingen konfirmere, med mindre de havde tilstrækkelige Kundskaber om de guddommelige Sandheder. Til hans Undskyldning kan det muligt tjene, at Sognet var fattigt, og at Befolkningen var uvilligt indstillet mod Skolegangen, der forhindrede den $\mathrm{i}$ helt at udnytte deres Børn til Knipleriet. Derfor bar det heller ingen Frugt, at Degnen Søndag Eftermiddag i Arnum forsøgte at udlægge Katekismen for de unge, der ikke gik i Kirke; selv Præsten var Modstander af disse Forsamlinger. Hvor uudviklet 
Egnen var, ses af, at en fremmed Person, der 1753 var kommet til Sognet, satte det fuldstændig paa den anden Ende ved at optræde som Doktor, Kvaksalver og Prædikant. Der var stor Tilstrømning til hans Hus i Arnum, hvor han prædikede for sine Patienter og om Aftenen, iklædt en hvid Skjorte og med Papirkrave om Halsen, læste og bad med de tilstedeværende, holdt Tale om Hekseri og endogsaa skulde have lyst Velsignelsen over dem - for bagefter at slutte Sammenkomsten med Spil og Dans. Præsten Jens Scherning (1752-63) magtede ikke Forholdene og klagede sig ynkeligt for Brorson, som paa sin Visitats 1754 havde Manden for sig i Præstegaarden. Det hjalp noget, men der vedblev dog endnu i de følgende Aar at være en vis Uro om ham i Sognet.

Som det vil fremgaa af ovenstaaende, blev Pietismen lige saa lidt i den sønderjydske Del af Ribe Stift som andetsteds i Landet den Folkebevægelse, dens Førere havde haabet, den skulde blive. ${ }^{68}$ ) Den førtes frem i lokale Kredse af stedlige Præster, der var grebet af den, men idet de paa gammel statskirkelig Vis kun betragtede deres egne Pastorater som sig vedkommende og derfor ikke befattede sig med nogen missionerende Virksomhed i andres, kom det Røre, de eventuelt vakte hjemme i deres Sogne, ikke til at øve Indflydelse udenfor dem. Naturligvis kunde fremmede søge til deres Kirker, men det ses ikke, at dette har ført til Dannelse af pietistiske Samfund i Nabolaget, som man saa muligvis kunde have ventet. Som før antydet var den hallensiske Pietisme, sin Tale om det almindelige Præstedømme til Trods, i Praksis lige saa statskirkelig som den gamle Ortodoksi og som den en aristokratisk Aandsretning, for saa vidt som den ikke formaaede at frigøre sig fra den overlevende Betragtning af den jævne Mands Uformuenhed til kristeligt at staa paa egne Ben. Derfor stillede den de gudelige Forsamlinger under gejstlig Kontrol (Konventikelplakaten 1741), og Lægmandsforkyndelse taaltes ikke, men Følgen blev rigtignok. at det som en almindelig Regel kom til at gælde, at 
Pietismen ikke kunde trives uden netop der, hvor der var en den velsindet Præst. De Ungdomsmøder, Degnen i Arnum prøvede at afholde, ser da heller ikke ud til at have fort til noget.

Som Pietismen var sognebegrænset, var den ogsaa tidsbegrænset. Brorsons ofte genkommende Ord om Vækkelser for en Del Aar siden viser, at de ikke har kunnet holde sig som Faktorer i Pastoraternes aandelige Liv - det samme som kan iagttages i andre Egne af Landet - et Vidnesbyrd om, at de mere er opstaaet som Følge af en opblussende Stemning end betinget af en virkelig Forstaaelse og Grebethed. Dette maa dog ikke opfattes saadan, at Pietismen slet ingen Indflydelse fik de paagældende Steder. Nogle ægte Rester er der vel altid blevet tilbage fra Vækkelsesperioden, hvor længe de saa ellers har holdt sig, og desuden kommer man næppe udenom, at Præsternes stærke Betoning af saavel det kristelige som det moralske Ideal og deres Henvendelse til den enkelte om at realisere det i sit Liv kan have haft sin Betydning og sat sine Spor i det daglige. I denne Forbindelse vil det forøvrigt være rimeligt at minde om, at der gennem Pontoppidans Forklaring, som ret hurtigt blev indført overalt, forkyndtes en pietistisk Livsanskuelse ogsaa i de Sogne, hvor Præst og Degn ellers tog Afstand fra Bevægelsen. Hvor meget saa dette har betydet, er en anden Sag, men man kan dog ikke helt lukke Øjnene for, at der ad den Vej er blevet givet en og anden Tilskyndelse, som har faaet Indflydelse paa den Retning, hans Udvikling senere kom til at tage.

Pietismens Tidsbegrænsethed gælder dog næppe for Døstrups Vedkommende. Her lød der nemlig en pietistisk Forkyndelse $\mathrm{i}$ omtrent $100 \mathrm{Aar}$, og selv om man ikke kender Antallet af de vakte i Sognet, er der al Grund til at tro, at den ikke har lydt forgæves, men virkelig har faaet Tag $i$ og præget betydelige Dele af Befolkningen, der ser ud til villigt at have sluttet op om sine Præster og det Arbejde, de satte i Gang.

Naar de pietistiske Præster, deres gode Vilje til Trods, alligevel ikke fik den Indflydelse i deres Sogne, som de havde haa- 
bet, maa Grunden ogsaa i nogen Maade søges i, at de tidt forkyndte Loven mere end Evangeliet og med deres stærke Ord og Krav ikke var i Stand til ret at gribe deres Tilhørere om Hjertet. Det var langt fra alle, der kunde prædike som $\mathrm{H}$. A. Brorson, til hvis paa een Gang milde og indtrængende Tale Fo!k gerne lyttede, saa de, scm han ofte beretter i sine Visitatsoptegnelser, baade blev „attente“ og bevægede. Naar derfor Herrnhutismen, som Biskoppen iøvrigt bortset fra det kirkepoßitiske i mange Henseender stod nær, i det lange Lob kom til at spille en betydelig større Rolle $i$ den sønderjydske Befolknings aandelige Liv, end Pietismen gjorde det, skyldes det for $€ n$ stor Del, at den formaaede at tage nogle af de samme Toner ligesom sikkert ogsaa dens Emissærer, der i Reglen var Mænd uden nogen akademisk Uddannelse, i sig selv havde bedre Betingelser for at udtrykke deres Tanker $i$ et jæunt og for Almuen fatteligt Sprog, end Tilfældet mange Gange var med Præsterne. Heller ikke maa det glemmes, at Herrnhutismen virkelig var en folkelig og lavkirkelig Bevægelse, der i langt højere Grad end Pietismen drog den jævne Mand med ind i Arbejdet i sine gudelige Forsamlinger. Dermed lærte dens Smaasamfund at staa paa egne Ben, ligesom den Forbindelse, Kredsene indbyrdes opretholdt gennem Rejseprædikanternes Besøg, der foretoges uden Hensyn til ellers skillende Sognegrænser, baade var af stor Betydning for Trivslen af det aandelige Liv i dem og gav deres Medlemmer en helt anden Følelse af Fællesskab end den, der var kendt i de pietistiske Konventikler.

Derfor virkede Herrnhutismen ogsaa dragende paa mange Pietister, selv blandt Præsterne, og ikke faa sluttede sig til den, mens deres egne Kredse sygnede hen. Her landt de noget af det, de hidtil ofte havde savnet, en glad Kristendom, der ikke som tidt den pietistiske var tung og mork og fyldt med Angst for ikke at kunne fyldestgøre de Krav, der stilledes til en, og en virkelig evangelisk Forkyndelse, der ikke gjorde visse aandelige Oplevelser til det afgørende, men var en mild Indbydelse til at give sig Gud i Vold, saadan som man var. Rent 
umiddelbart har de sikkert ogsaa befundet sig vel i de af Lægmænd stilfærdigt ledede Forsamlinger. Det vil sige, at Herrnhutismen traadte i den hensygnende Pietismes Sted. Heller ikke den blev ganske vist nogen Folkebevægelse, men alligevel kom den i Kraft af Egenskaber som de foran næunte til at spille en større Rolle, end man efter Antallet af dens Venner kunde have formodet, og navnlig efter Christiansfelds Anlæggelse at øve en ikke helt ringe Indflydelse paa det sønderjydske Kirkeliv.

Spørgsmaalet om der fra den nordvestslesvigske Pietisme, saaledes som den udfoldede sig i Sognene, har gaaet Traade til de kongerigske Vækkelser, maa ud fra dens lokalt begrænsede og præsteledede Karakter besvares benægtende. Vel kunde unge Nørrejyder, der tjente "sønderude“, dér blive grebet af Bevægelsen og efter deres Hjemkomst gøre sig til Talsmænd for den blandt deres Bysbørn, men da det kun er en enkelt Gang, man hører om sligt (Brorsons Visitats $1742 \mathrm{i} \mathrm{Moborg}){ }^{69}$ ) er det rettest ikke at bygge for meget derpaa. Vækkelserne Nord for Kongeaaen artede sig $i$ det he'e paa samme Maade som Syd for den, sognebestemte og hidført af den stedlige Gejstlighed, saa der er ingen Grund til at forudsætte nogen direkte Indflydelse fra nordvestslesvigsk Menighedsliv.

En anden Sag er det, at nogle af den kongerigske Pietismes ledende Skikkelser var fra Nordslesvig og havde mødti Vækkelsen der. For saa vidt kan der indirekte tales om den Indflydelse, Kirkelivet Syd for Kongeaaen gennem dem har haft paa Forholdene $i$ det egentlige Danmark, kun maa det betones, at disse Mænd (Evald,Brødrene Brorson, P. Jacobsen Hygom o. a.) ikke kom med en særlig sønderjydsk Pietisme - en saadan eksisterede ikke - men med Pietismen, saadan som enhver af dem forstod den, og at deres Forkyndelse derfor og svarende til hver enkelts Personlighed fremtraadte og maatte fremtræde med forskelligt Præg de forskellige Steder, saa med dette Forbehold er der intet $\mathrm{i}$ Vejen for at tale om den Gæld, hvori vi i Kongeriget staar i den nordvestslesvigske Pietisme 


\section{Noter og Henvisninger}

1) Fra Ribe Amt 1945, S. 223 ff. Kirkeh. Saml. 4-I, S.503 ff. 2) Ribe Bispesæde $948-1948$, S. 248 ff. Jf. Hg. Matthiessen: Hærvejen, S. $14 \mathrm{ff} .{ }^{3)}$ Slesvigs delte Bispedømme, S. $179 \mathrm{ff}$. ") Sstds., S. 191. 5) I kirkelige Anliggender. ") Ribe Bispesæde, S. 253. 7) Fra Ribe Amt V, S. 485. Aagaard: Beskr. af Tørning Len, S. 23. $\left.{ }^{8}\right)$ Ribe Bispeark.: Møgeltdr. Herreds Pk. 1583 ff (Landsark., Aabenraa). ') N. Rangstr. Her. Pk. $1586 \mathrm{ff}$ (Aabenraa). 10) L $\phi$ Her. Pk. $1740 \mathrm{ff}$ (Aabenraa). 11) Sdj. Aarbg. 1941, S. 87. 12) N, Rangstr. Hem. Pk. 1586 ff. ${ }^{13)}$ Sl. delte Bisped. S. $\left.180 .{ }^{14}\right)$ L. Moltesen: Fr. Brekling. 15) E. Hansen: Geschichte d. Konfirmat. in Schl.-Holst. S. 160 f. $\left.{ }^{10}\right)$ Personalhist. Tidsskr. 11-5. S. 185. Aug. Evald se Litteraturhenvisninger i D. biogr. Lex. VI, S. 477. ${ }^{17}$ ) quibus verbis, quo animo et qua intentione. ${ }^{18}$ ) superiores. 19) Om N. Brorson se Kirkeh. Saml. 3-VI, S. $665 \mathrm{ff}$. 20) Carsten Petersen: S1. Præster, S. 94. 21) B. Brodersen: Fra gl. Dage, S. 359. Jf. Pontoppidans Skildring i Menoza (Brev XL VIII), der maaske hentyder til Forholdene i Lфgumkl. ${ }^{22}$ ) Ribe Bispesæde, S. 161 f. ${ }^{23}$ ) Carsten Petersen, S. 94. $\left.{ }^{24}\right)$ Kirkeh. Saml. 5-IV, S. 586. ${ }^{25}$ ) Sstds., S. 567. Jørgensen: Chronik des Kirchspiels Døstrup (Landsark. Aabenrea). Sdj. Aarb. 1901, S. 336; 1923, S. 210 ff. M. H. Nielsen: Fra Slesvig Fattigvæsens Fortid, S. 17 ff. ${ }^{26}$ ) $\rightarrow$ Te rabiat Diabolus nisi mature destiteris a lite Sanctulo Døstrupiensi illata. ${ }^{27}$ ) Schriften des Vereins für schl.-holst. Kirchengeschichte 2-IX, S. 497 ff. ${ }^{28}$ ) Hvad det er for en Broder, oplyses ikke, og der kan næppe være sigtet til Præsten i Reisby. Muligt foreligger der en Fejlskrivning eller Fejllæsning. $\left.{ }^{29}\right)$ Féci quod potui; potui quod, Christi, dedisti. - Si bene quid dixi, gloria, Christe tua est.* — Tam recens mihi est Christus, ac si hac hora fudisset sangvinem. . De forste Sætninger er formet som et Disticon, afvekslende Hexameter og Pentameter. 30) Ribe Bispeark.: Miscell, S. 61, Nr. 33, Rev. 7 (Landsark. Viborg). 31) Ribe Bispesæde, S. 142. 32) F. Elle Jensen: Pietismen i Jylland, S. 127. \$s) Lø Herr. Pk. $1740 \mathrm{ff}$. ${ }^{34}$ ) "modus tractandi, proponendi et applicandi.* ${ }^{35}$ ) Mnemo- 
syne 4, S. 401 f. ${ }^{33}$ ) Ribe Bispeark.: Miscell. S. 61, Nr. 33, Rev. 7. ${ }^{37}$ ) Brodersen, S. 249. ${ }^{\text {s8) }}$ Kirkeh. Saml. 4-I, S. 674. ${ }^{39}$ ) Brodersen, S. 307. 41) Wibergs Præstehist. III, S. 595. ${ }^{41}$ ) Brodersen, S. 319 ff. Sdj. Aarb. 1923, S. 209. ${ }^{42}$ ) Ribe Bispeark.: Miscell, S. 61, Nr. 33. ${ }^{43}$ ) Nielsen: Fra Slezvigs Fattigvæsens Fortid, S. $\left.19 \mathrm{f},{ }^{44}\right)$ Ribe Bispeark.: Miscell. S. 60, Nr. 28. ${ }^{45}$ ) Miscell. S. 61, Nr. 44. ${ }^{46}$ ) Kirkeh. Saml. 3-V, S. 712. Clausen i Mjolden fik en lignende Anbefaling. ${ }^{47}$ ) Mgltdr. Her. Pk. 1583 ff. 4*) Sdj. Aarb. 1936, S. $206 \mathrm{ff}$. $\left.{ }^{4 \theta}\right)$ Brodersen, S. $282 .{ }^{50}$ ) Sdj. Aarb. 1913, S. 254 ff. ${ }^{51}$ ) Om Jens Brock se Fra Himmerl. og Kær Herred, 1945 , S. 66 ff. ${ }^{52}$ ) Miscell. S. 60, Nr. 32. ${ }^{\text {s3) }}$ Heibergs Saml. t. Pietismens Hist. (Rigsark.). $\left.{ }^{54}\right)$ Brodersen, S. 200 ff. ${ }^{55}$ ) Gottholds zufällige Andachten, forfattet af $\mathrm{Chr}$. Scriver ( $\dagger 1693$ som Overhofprædikant $\mathrm{i}$ Quedlinburg). Hans mest kendte Bog var «Sjæleskat*. ${ }^{5 b}$ ) Carsten Petersen: Optegnelser om Præsterne i Tørning Len (Landsark. Aabenraa. 57) Ribe Bispeark.: Gram Her. Pk. 1626 ff (Landsark. Aabenraa). $\left.{ }^{5 \kappa}\right)$ Se Anm. 1. "5) Carsten Petersens Optegn. " ${ }^{\text {an }) ~ D e n ~ d a n s k e ~}$ Kirkes Hist. v. Koch og Kornerup, V, S. 209. "1) Brodersen, S. 243 ff. (i)) Ribe Bispeark.: Hviding Her. Pk. 1740 ff (Landsark. Viborg). "3) Sdj. Aarb. 1939, S. $107{ }^{64}$ ) Hviding Her. Pk. 1740 ff. (i5) Ribe Bispeark.: Kopibog 10. 8. 1756 (Landsark. Viborg). ${ }^{\text {B6}}$ ) Hviding Herr. Pt. 1740 ff. ${ }^{07}$ ) Arends Gejstlgh. i Sl.-Holst. II S. 114. ${ }^{68}$ ) Om Pietismens Forhold til Ortodoksi og Herrnhutisme henviser jeg til den udførligere Fremstilling i min Bog »Pietismen i Jylland Pietismen og Befolkningen. ${ }^{69}$ ) Pietism. i Jyll. S. 78. 